\title{
Analis Perbandingan Bank Umum Syariah Dengan Unit Usaha Syariah Dari Aspek Efisiensi; Kualitas Asset Dan Stabilitas Keuangan (Periode Tahun 2014-2017)
}

\author{
Lucky Nugroho \\ Fakultas Ekonomi dan Bisnis Universitas Mercu Buana, \\ Email: lucky.nugroho@mercubuana.ac.id \\ Fiki Wahyu Kuncoro \\ Fakultas Ekonomi dan Bisnis Universitas Mercu Buana, \\ Email: fikiwahyukuncoro@gmail.com \\ Akhmad Amien Mastur \\ Program Doktor Islamic Economics \& FinanceTrisakti University, \\ Email: amien_mastur@yahoo.co.id
}

\begin{abstract}
Abstrak:
This research aims to compare efficiency, quality of assets and financial stability between Sharia banks (BUSES) and Sharia business units (UUS). Efficiency variables are formulated with the ratio of operating costs compared to the operating income (BOPO), the quality of the asset is made in the ratio of non-performing financing (NPF), namely the comparison of problematic financing with total Financing, and financial stability that is redefined with Return On Asset (ROA) is a comparison of the profit generated by the bank with the total assets owned by the bank. The method in this research is the quantitative method of using descriptive test and $\mathrm{T}$ test. Based on the descriptive results and test $\mathrm{T}$, the efficiency, quality of assets and financial stability of the UUS is better when compared to the BUS.

[Penelitian ini bertujuan untuk membandingkan efisiensi, kualitas asset dan stabilitas keuangan antara bank umum syariah (BUS) dan unit usaha syariah (UUS). Variabel efisiensi diformulasikan dengan rasio biaya operasional dibandingkan dengan pendapatan operasional (BOPO), kualitas asset diproxykan dengan rasio non-performing financing (npf) yaitu perbandingan antara pembiayaan bermasalah dengan total pembiayaan yang disalurkan, dan stabilitas keuangan yang diproxykan dengan Return On Asset (ROA) yaitu perbandingan laba yang dihasilkan oleh bank dengan total asset yang dimiliki oleh bank. Metode dalam penelitian ini adalah metode kuantitatif yaitu memggunakan uji deskriptif dan uji T. Berdasarkan hasil deskriptif dan uji T, maka efisiensi, kualitas asset dan stabilitas keuangan dari UUS lebih baik apabila dibandingkan dengan BUS.]
\end{abstract}

Kata Kunci: Efisiensi; Kualitas Asset; Stabilitas Keuangan;. 


\section{PENDAHULUAN}

Industri perbankan merupakan pilar penting bagi perekonomian di suatu negara yang berfungsi untuk menunjang transaksi keuangan dan bisnis masyarakat. Oleh karenanya, pemerintah sangat peduli dan berkepentingan untuk menjaga stabilitas ekonomi dengan menjaga kesehatan keuangan dari industri perbankan, baik bank konvensional maupun bank syariah. ${ }^{1}$ Industri perbankan di Indonesia pernah mengalami masa krisis pada periode tahun 1997-1998 dimana terdapat bank-bank yang dilikuidasi dikarenakan kesulitan likuiditas akibat turunnya kepercayaan dari masyarakat. Namun demikian, pada periode tersebut eksistensi bank syariah tidak mengalami masalah likuiditas seperti halnya bank konvensional hal tersebut dimungkinkan karena bank syariah menerapkan prinsip-prinsip syariah yaitu "magrib", larangan transaksi maysir atau biasa disebut dengan transaksi yang mengandung unsur spekulasi atau judi, gharar yaitu transaksi yang belum jelas underlying-nya dan transaksi yang mengandung unsur riba. ${ }^{2}$ Oleh karenanya setelah kejadian krisis ekonomi dan moneter tersebut, banyak sekali peneliti yang ingin melakukan penelitian lebih lanjut terkait dengan kelebihan dan dampak dari bank syariah bagi masyarakat dan negara. Lebih lanjut, kondisi saat ini Perbankan syariah di Indonesia telah mengalami pertumbuhan dalam hal kelembagaan. Menurut laporan Otoritas Jasa Keuangan, sampai dengan Desember 2017 telah terdapat 13 Bank Umum Syariah (BUS), 21 Unit Usaha Syariah (UUS), dan terdapat 167 Bank Pembiayaan Rakyat Syariah (BPRS) yang terletak pada wilayah seluruh Indonesia.

Secara umum konsep efisiensi merupakan perbandingan antara output dengan input. ${ }^{3}$ Selain itu, efisiensi juga merupakan kemampuan perusahaan menghasilkan output yang optimal dengan input atau sumber daya (source) yang dimiliki perusahaan. ${ }^{4}$ Untuk mendapatkan kepercayaan dari masyarakat dan juga menjaga keberlangsungan operasional bank syariah, maka salah satu rasio indikator keberhasilan adalah menjaga rasio efisiensi yang berdampak terhada optimalnya kinerja bank syariah. Apabila kegiatan operasional perbankan syariah di Indonesia semakin efisien didalam melaksanakan fungsi intermediarinya, maka semakin memiliki keunggulan dalam bersaing dengan bank konvensional. Oleh karenanya, efisiensi yang optimal dari bank syariah akan mampu memberikan tingkat pengembalian yang lebih bersaing sehingga akan berdampak terhadap meningkatnya kesejahteraan bagi para nasabah pada khususnya dan masyarakat pada umumnya. Selain itu, dampak dari efisiennya dan baiknya kinerja dari bank syariah yang notabene bank yang memiliki kepedulian dan fokus terhadap aspek sosial dan lingkungan, maka akan menambah nilai perusahaan dari bank syariah tersebut serta menumbuhkan

\footnotetext{
1 Soeharjoto Soekapdjo, Debbie Aryani Tribudhi, and Lucky Nugroho, "Pengaruh Fundamental Ekonomi Dan Kinerja Keuangan Terhadap Kredit Bermasalah Pada Bank Syariah Di Indonesia," Ekonika: Jurnal Ekonomi Universitas Kadiri 4, no. 2 (2019): 126, https://doi.org/10.30737/ekonika.v4i2.327.

2 Lucky Nugroho et al., "Maslahah and Strategy to Establish A Single State-Owned Islamic Bank in Indonesia," Tazkia Islamic Finance and Business Review 10, no. 1 (June 1, 2017): 17-33, http://www.tifbrtazkia.org/index.php/TIFBR/article/view/97/106; Citra Sukmadilaga and Lucky Nugroho, Pengantar Akuntansi Perbankan Syariah "Prinsip, Praktik Dan Kinerja" (Pusaka Media, Bandar Lampung, Indonesia, 2017); Heri Sudarsono, "Dampak Krisis Keuangan Global Terhadap Perbankan Di Indonesia: Perbandingan Antara Bank Konvensional Dan Bank Syariah," La_Riba 3, no. 1 (2009): 12-23, https://doi.org/10.20885/lariba.vol3.iss1.art2.

3 Mumu Daman Huri, dan Indah Susilowati. "Pengukuran Efisiensi Relatif Emiten Perbankan Dengan Metode Data Envelopment Analysis (DEA) (Studi Kasus: Bank-Bank Yang Terdaftar Di Bursa Efek Jakarta Tahun 2002).” Jurnal Dinamika Pembangunan (JDP) 1, no. 2 (2004): 95-110.

4 Fantika Vera Entrisnasari, "Analisis Portofolio Optimum Saham Syariah Menggunakan Mean Semivarian," JURNAL FOURIER 4, no. 1 (2015): 41-57; I M Premachandra and Jing Shi, "Measuring the Relative Efficiency of Fund Management Strategies in New Zealand Using a Spreadsheet-Based Stochastic Data Envelopment Analysis Model," Omega 26, no. 2 (1998): 319-31, https://doi.org/10.1016/S0305-0483(98)00002-4.
} 
tingkat kepercayaan dari masyarakat terhadap bank syariah. ${ }^{5}$ Kepercayaan masyarakat terhadap bank syariah merupakan unsur yang vital karena akan memberi dampak bertambahnya nasabah bank syariah tersebut dan akan mengakibatkan keuntungan bank syariah juga semakin meningkat. Berikut terdapat rasio perkembangan BOPO antara bank umum Syariah dan unit usaha Syariah.

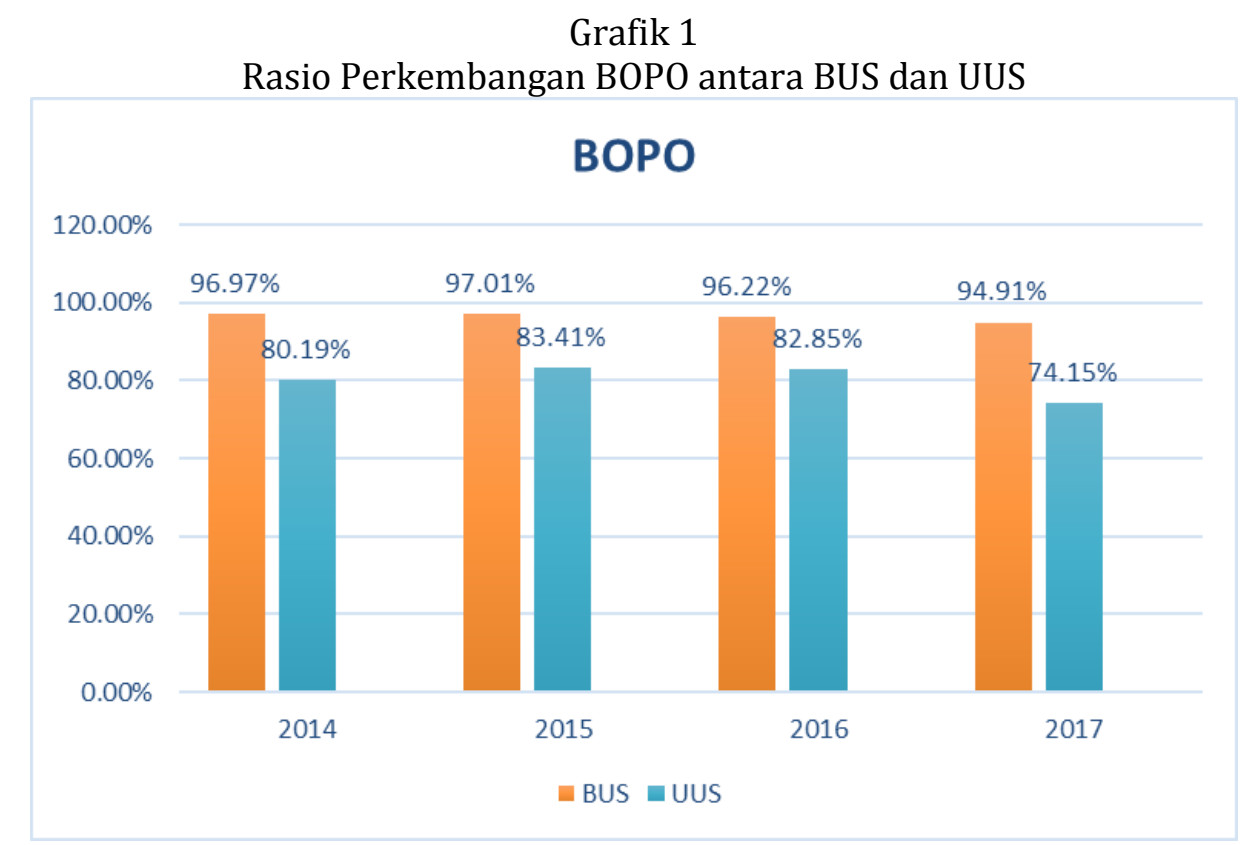

Sumber : www.ojk.go.id 2014-2017

Dapat disimpulkan dari grafik 1 bahwa rasio perkembangan BOPO antara bank umum Syariah dan unit usaha Syariah mengalami pertumbuhan yang fluktuatif. Pada tahun 2015 BOPO pada bank umum Syariah mengalami kenaikan yang signifikan yaitu menjadi sebesar 97,01\% sedangkan pada tahun 2017 bank umum Syariah mengalami penurunan menjadi sebesar 94,91\% yang berarti Bank Umum Syariah memiliki kemampuan melakukan efisiensi biaya operasional yang optimal. Namun pada Unit usaha syariah pada tahun 2015 BOPO mengalami kenaikan yang signifikan yaitu menjadi sebesar 83,41\%. Pada tahun 2016 dan 2017 Unit Usaha syariah mengalami penurunan menjadi sebesar 82,85\% dan 74,15\%. Oleh karenanya secara industri UUS memiliki efisiensi yang ditunjukkan oleh indikator BOPO yang lebih baik dibandingkan dengan BUS.

Konsep dari kualitas aset adalah kemungkinan kembalinya dana yang telah diinvestasikan dalam bentuk pembiayaan atau yang lazim disebut dengan aktiva produktif. Selanjutnya, indikator keuangan yang digunakan untuk mengukur tingkat baik atau buruknya kualitas aset adalah Non Performing Financing (NPF). Rasio NPF menjadi indikator yang

\footnotetext{
5 C J Cowton, "Integrity, Responsibility and Affinity: Three Aspects of Ethics in Banking 1," Business Ethics: A European Review 11, no. 4 (2002): 393-400; Willy Arafah and Lucky Nugroho, "Maqhashid Sharia in Clean Water Financing Business Model at Islamic Bank," International Journal of Business and Management Invention (IJBMI) 5, no. 2 (May 1, 2016): 22-32, http://www.ijbmi.org/papers/Vol(5)2/Version -3/D05203022032.pdf; Lucky Nugroho, Nurul Hidayah, and Ahmad Badawi, "The Islamic Banking, Asset Quality: 'Does Financing Segmentation Matters' (Indonesia Evidence)," Mediterranean Journal of Social Sciences 9, no. 5 (2018): 221-35, https://doi.org/10.2478/mjss-2018-0154; Lucky Nugroho, Ahmad Badawi, and Nurul Hidayah, "Discourses of Sustainable Finance Implementation in Islamic Bank (Cases Studies in Bank Mandiri Syariah 2018)," International Journal of Financial Research 10, no. 6 (2019): 108-17, https://doi.org/10.5430/ijfr.v10n6p108.
} 
menunjukkan apabila rasio NPF semakin tinggi, maka akan semakin buruk kualitas dari penyaluran atau pemberian pembiayaan dari bank tersebut. Buruknya kualitas pembiayaan dapat menyebabkan kerugian, sebaliknya jika semakin rendah NPF maka laba atau profitabilitas bank (ROA) tersebut akan diharapkan dapat semakin meningkat. ${ }^{6}$ Berikut rasio perkembangan NPF pada bank umum Syariah (BUS) dan unit usaha Syariah (UUS).

\section{Grafik 2}

Rasio Perkembangan NPF pada BUS dan UUS

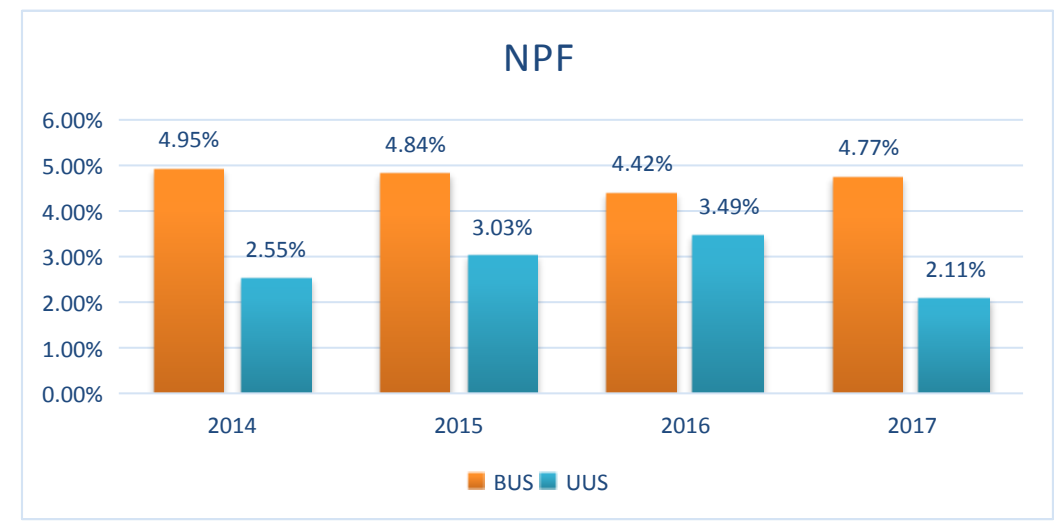

Sumber : www.ojk.go.id 2014-2017

Dapat dideskripsikan dari grafik 2 bahwa rasio perkembangan NPF pada bank umum Syariah tetap stabil diangka 4\% yang hampir menyentuh angka 5\% yang merupakan batas maksimal yang telah ditentukan oleh Bank Indonesia (BI) dan Otoritas Jasa Keuangan (OJK). Sedangkan rasio perkembangan NPF pada unit usaha Syariah mengalami pergerakan yang fluktuatif yaitu menjadi sebesar 2,11\% pada tahun 2017 dimana kondisi NPF dari unit usaha syariah tersebut menunjukkan kualitas produktif yang lebih baik apabila dibandingkan dengan bank umum syariah.

Stabilitas Bank atau Stabilitas keuangan pada lembaga keuangan dapat dikatakan sebagai kebalikan dari kerentanan atau instabilitas keuangan. Merujuk kepada situasi berjalannya fungsi kelembagaan (stabilitas perbankan) dan pasar yang membentuk sistem keuangan. Lebih lanjut, stabilitas keuangan dan moneter merupakan prasayarat utama berfungsinya sebuah sistem ekonomi. Kerentanan keuangan akan menciptakan situasi ketidakpastian yang berbahaya yang akan mengarah kepada mislokasi sumber daya dan keengganan melakukan investasi. ${ }^{7}$ Pada kondisi yang ekstrim, gangguan pada sektor keuangan akan mengakibatkan dampak yang sangat buruk pada aktifitas perekonomian dan bahkan pada stabilitas politik. Dengan demikian memelihara stabilitas keuangan adalah tujuan utama dari bank sentral dan otoritas keuangan. ${ }^{8}$

6 Riski Agustiningrum, "Analisis Pengaruh CAR, NPL, Dan LDR Terhadap Profitabilitas Pada Perusahaan Perbankan." Jurnal Manajemen Universitas Udayana 2, no. 8 (2013): 885-902. Lihat juga, Anisah, Lubis. "Pengaruh Tingkat Kesehatan Bank Terhadap Pertumbuhan Laba Pada BPR Di Indonesia." Jurnal Ekonomi Dan Keuangan, 1, no. 4 (2013): 27-37.

7 Azifah Azka Dienillah and Lukytawati Anggraeni, "Dampak Inklusi Keuangan Terhadap Stabilitas Sistem Keuangan Di Asia," Buletin Ekonomi Moneter Dan Perbankan 18, no. 4 (2016): 409-30; Elizabeth Asiedu, "The Role of Natural Resources, Market Size, Government Policy, Institutions and Political Instability," World Institute for Development Economics Research Working Paper 2005, no. 24 (2005).

8 Sri Haryati, "Pertumbuhan Kredit Perbankan Di Indonesia: Intermediasi Dan Pengaruh Variabel Makro Ekonomi," Jurnal Keuangan Dan Perbankan 13, no. 2 (2009): 299-310; Milton Friedman, "The Role of Monetary 
Grafik 3

Rasio Perkembangan ROA pada BUS dan UUS

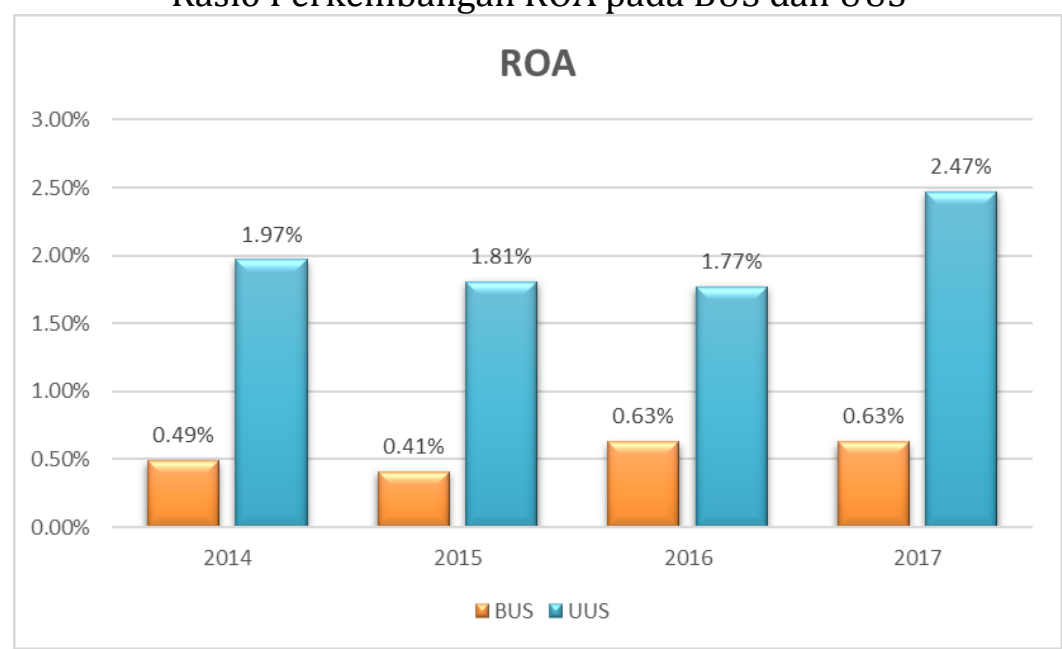

Sumber : www.ojk.go.id 2014-2017

Pada grafik 3 di atas, dapat diketahui bahwa rasio perkembangan ROA antara bank umum syariah dan unit usaha syariah mengalami pertumbuhan yang fluktuatif. Pada tahun 2015 ROA pada bank umum syariah mengalami penurunan sebesar $0.41 \%$ sedangkan pada tahun 2016 dan 2017 bank umum syariah mengalami kenaikan menjadi sebesar 0,63\% yang berarti bank umum syariah dapat memperbaiki kinerja laba bersih melalui pemberdayaan aset-aset yang dimiliki secara optimal. Namun pada unit usaha syariah pada tahun 2015 ROA mengalami penurunan yaitu sebesar 1,81\%. Pada tahun 2016 mengalami penurunan kembali yaitu sebesar 1,77\% dan pada tahun 2017 Unit Usaha syariah mengalami kenaikan yang begitu pesat, yaitu menjadi sebesar 2,47\%.

Berdasarkan fenomena diatas yang terjadi pada tahun 2017 bahwa bank umum syariah memiliki aset yang lebih besar apabila dibandingkan dengan unit usaha syariah. Dimana bahwa aset bank umum syariah mencapai 288,02 triliun sedangkan aset unit usaha syariah sebesar 136,15 triliun. Berdasarkan dari hasil penelitian dan data-data di atas, maka peneliti memandang penting untuk melakukan penelitian lebih lanjut terkait "Analisa Perbandingan Efisiensi, Kualitas Aset, dan Stabilitas Keuangan antara UUS dan BUS". Objek penelitian adalah Bank Umum Syariah, sedangkan tahun penelitian adalah periode 20142017. Adapun tujuan penelitian ini bertujuan untuk mengetahui perbedaan antara bank umum syariah dengan unit usaha Syariah dari aspek efisiensi kualitas aset dan stabilitas keuangan.

\section{METODE PENELITIAN}

Metode yang digunakan dalam penelitian menggunakan metode kualitatif deskriptif yaitu menggambarkan hubungan variabel yang ada dalam penelitian ini. Adapun variabel dalam penelitian adalah: Efisiensi, Kualitas Aset dan Stabilitas Keuangan. Kerangka pemikiran pada penelitian ini terdapat pada gambar 1 di bawah ini:

Policy," Essential Readings in Economics LVIII, no. 1 (1968): 215-31; Bernd Hayo, "Inflation Culture, Central Bank Independence and Price Stability," European Journal of Political Economy 14, no. January (1998): 241-63. 
Analis Perbandingan Bank Umum Syariah Dengan Unit Usaha Syariah Dari Aspek Efisiensi; Kualitas Asset Dan Stabilitas Keuangan (Periode Tahun 2014-2017)

Gambar 1.

Kerangka Pemikiran

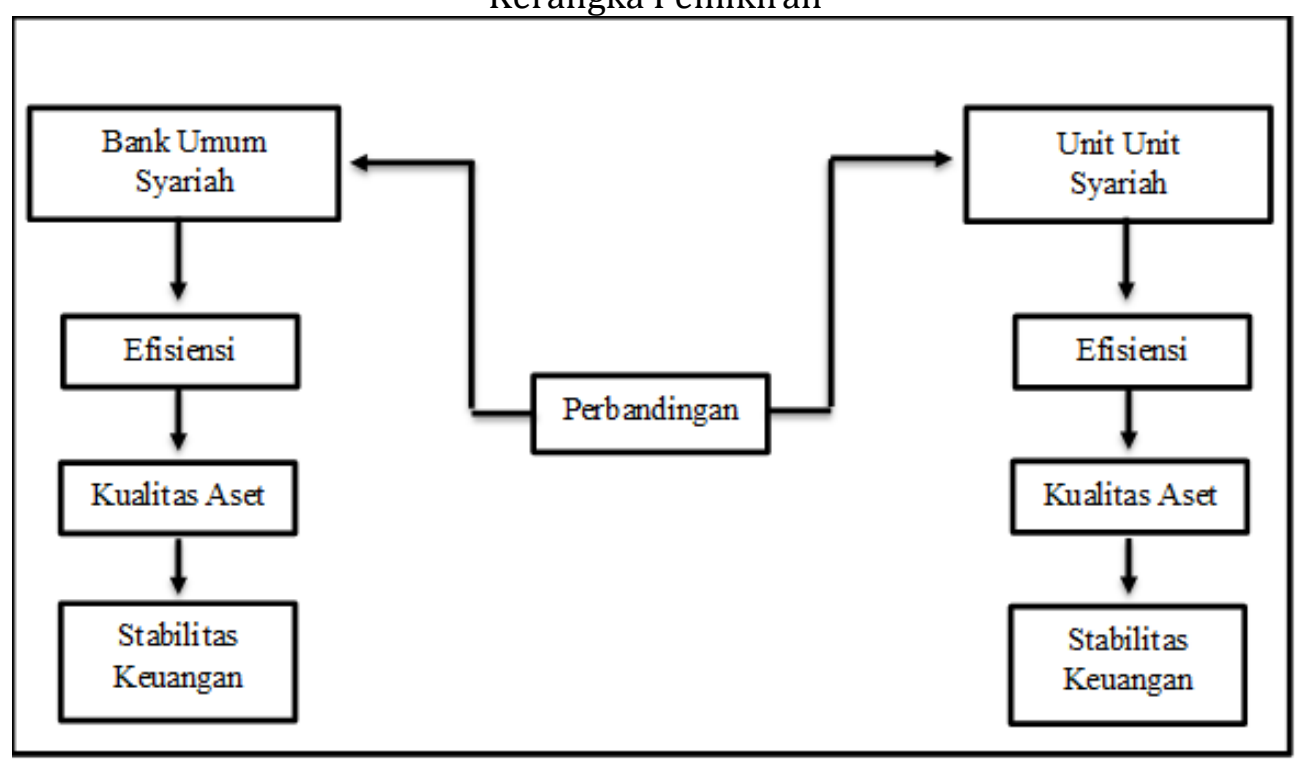

Berdasarkan kerangka pemikiran di atas dapat dijelaskan bahwa metode yang yang digunakan dalam penelitian ini adalah membandingkan aspek efisiensi, kualitas aset dan stabilitas keuangan antara bank umum syariah dengan unit usaha syariah. Penelitian ini bertujuan untuk mengetahui perbandingan tiga variabel, yaitu efisiensi, kualitas aset, dan stabilitas antara bank umum syariah dengan unit usaha syariah di Indonesia. Pada dasarnya penelitian ini merupakan replikasi dengan beberapa modifikasi dari penelitian-penelitan terdahulu, dengan demikian penelitian ini bertujuan melakukan analisa perbedaan ketiga aspek tersebut pada bank umum syariah dan unit usaha syariah yang merujuk pada penelitian sebelumnya yang telah dilakukan oleh: Suraya Ahmad dan Abdul Rahim Abdul Rahman; ${ }^{9}$ Beck, dkk.; ${ }^{10}$ Satibi dan Umami; ${ }^{11}$ Bachruddin; ${ }^{12}$ dan Satibi dkk. ${ }^{13}$ Berdasarkan kerangka pemikiran tersebut di atas (gambar 1), maka hipotesis dalam penelitian ini adalah sebagai berikut:

H1: Terdapat perbedaan Efisiensi antara Bank Umum Syariah dan Unit Usaha Syariah;

H2: Terdapat perbedaan Kualitas Aset antara Bank Umum Syariah dan Unit Usaha Syariah;

H3: Terdapat perbedaan Stabilitas antara Bank Umum Syariah dan Unit Usaha Syariah.

\footnotetext{
${ }_{9}^{9}$ Ahmad, Suraya, and Abdul Rahim Abdul Rahman. "The Efficiency of Islamic and Conventional Commercial Banks in Malaysia." International Journal of Islamic and Middle Eastern Finance and Management 5, no. 3 (2012): 241-63. https://doi.org/10.1108/17538391211255223.

10 Beck, et. all., "Islamic Vs . Conventional Banking: Business Model, Efficiency and Stability Islamic vs . Conventional Banking Business Model , Efficiency and Stability." Journal of Banking \& Finance 37, no. October (2010): 433-47. https://doi.org/10.1016/j.jbankfin.2012.09.016.

11 Elsa Satibi, and Wiwik Utami. "Studi Komparasi Efisiensi, Kualitas Aset Dan Stabilitas Pada Bank Umum Syariah Dan Bank Umum Konvensional Di Indonesia Periode 2010-2014." Jurnal Ilmu Ekonomi Dan Sosial 4, no. 1 (2015): 104-14.

12 Bachruddin. "Pengukuran Tingkat Efisiensi Bank Syariah Dan Bank Konvensional Di Indonesia Dengan Formula David Cole's Roe for Bank." Jurnal Siasat Bisnis (JSB) 11, no. 1 (2006): 67-80.

13 Elsa "A Comparison of Sharia Banks and Conventional Banks in Terms of Efficiency, Asset Quality and Stability in Indonesia for the Period 2008-2016." International Journal of Commerce and Finance 4, no. 1 (2018): 134-49.
} 


\section{HASIL DAN PEMBAHASAN \\ Gambaran Umum Obyek Penelitian}

Populasi dalam penelitian ini adalah seluruh Bank Umum Syariah (BUS) dan Unit Usaha Syariah (UUS) yang terdaftar pada Otoritas Jasa Keuangan (OJK) selama periode tahun 2014-2017. Berdasarkan metode purposive sampling terdapat 8 bank umum syariah dan 17 unit usaha syariah dengan tahun pengamatan 4 tahun, jadi dapat disimpulkan terdapat $8 \times 4$ $=32$ bank umum syariah dan 17 x $4=68$ unit usaha syairah.

\section{Hasil Uji Statistik Deskriptif}

Analisis statistik deskripsif bertujuan untuk mendeskripsikan variabel-variabel penelitian meliputi distribusi frekuensi, baik dalam jumlah, maupun nilai mean terhadap masing-masing indikator yang ada pada jumlah efisiensi, kualitas aset, dan stabilitas. Penelitian ini menggunakan data sekunder yang didapatkan dari annual report untuk masingmasing bank. Bank yang memenuhi kriteria dari penelitian ini sebanyak 100 sampel yang dibagi menjadi bank umum syariah dan unit usaha syariah.

Tabel 1

Hasil Uji Statistik Deskriptif BOPO

\begin{tabular}{ccccccc}
\hline Indikator & Bank & N & Min & Max & Mean & Std.Dev \\
\hline \multirow{2}{*}{ BOPO } & BUS & 32 & 68,80 & 99,51 & 89,5559 & 8,16584 \\
& UUS & 68 & 60,13 & 96,61 & 78,2729 & 7,78147 \\
\hline
\end{tabular}

Sumber : Data yang diolah menggunakan spss 21

Berdasarkan hasil statistik deskriptif BOPO tabel 1 di atas, dapat diketahui bahwa jumlah sampel dalam penelitian ini adalah bank umum syariah dan unit usaha syariah pada periode tahun 2014-2017 yang terdiri dari 32 bank umum syariah dan 68 unit usaha syariah. Adapun rata-rata nilai efisiensi yang diproksikan dengan rasio BOPO pada bank umum syariah adalah sebesar 89,55 angka tersebut lebih besar jika dibandingkan dengan rasio BOPO pada unit usaha syariah sebesar 78,27 hal tersebut menunjukkan bahwa unit usaha syariah lebih efisien dibandingkan dengan bank umum syariah. Adapun nilai minimum efisiensi yang diproksikan oleh BOPO pada bank umum syariah adalah sebesar 68,80 yaitu pada bank tabungan pensiunan nasional syariah pada tahun 2017, sedangkan nilai minimum unit usaha syariah sebesar 60,13 yaitu pada BPD Sulawesi Barat dan Sulawesi Selatan pada tahun 2016. Nilai maksimum bank umum syariah adalah sebesar 99,51 yaitu pada bank mega syariah tahun 2015, sedangkan nilai maksimum unit usaha syariah adalah sebesar 96,61 yaitu pada bank danamon Indonesia tahun 2014. Nilai penyimpangan bank umum syariah sebesar 8,16 sedangkan pada unit usaha syariah nilai penyimpangan sebesar 7,78.

Tabel 2

Hasil Uji Statistik Deskriptif NPF

\begin{tabular}{ccccccc}
\hline Indikator & Bank & N & Min & Max & Mean & Std.Dev \\
\hline \multirow{2}{*}{ NPF } & BUS & 32 & 0.04 & 4,76 & 1,9634 & 1,59292 \\
& UUS & 68 & 0,10 & 4,77 & 1,8950 & 1,32848 \\
\hline
\end{tabular}

Sumber : Data yang diolah menggunakan spss 21

Berdasarkan hasil statistik deskriptif NPF tabel 2 di atas, dapat diketahui bahwa jumlah sampel dalam penelitian ini adalah bank umum syariah dan unit usaha syariah pada periode tahun 2014-2017 yang terdiri dari 32 bank umum syariah dan 68 unit usaha syariah. Adapun rata-rata nilai kualitas aset yang diproksikan dengan rasio NPF pada bank umum 


\section{Analis Perbandingan Bank Umum Syariah Dengan Unit Usaha Syariah Dari Aspek Efisiensi; Kualitas Asset Dan Stabilitas Keuangan (Periode Tahun 2014-2017)}

syariah adalah sebesar 1,96 angka tersebut lebih besar jika dibandingkan dengan rasio NPF pada unit usaha syariah sebesar 1,89 hal tersebut menunjukkan bahwa bank umum syariah memiliki kualitas aset yang lebih rendah apabila dibandingkan dengan unit usaha syariah. Adapun nilai minimum kualitas aset yang diproksikan oleh NPF pada bank umum syariah adalah sebesar 0,04 yaitu pada bank BCA syariah dan Bank Aceh Syariah pada tahun 2017, sedangkan nilai minimum unit usaha syariah sebesar 0,10 yaitu pada BPD Jambi dan BPD Kalimantan Barat pada tahun 2017 \& 2014. Nilai maksimum bank umum syariah adalah sebesar 4,76 yaitu pada bank Muamalat Indonesia tahun 2014, sedangkan nilai maksimum unit usaha syariah adalah sebesar 4,77 yaitu pada BPD Jawa Timur tahun 2016. Nilai penyimpangan bank umum syariah sebesar 1,89 sedangkan pada unit usaha syariah nilai penyimpangan sebesar 1,32.

Tabel 3

Hasil Uji Statistik Deskriptif ROA

\begin{tabular}{lllllll}
\hline Indikator & Bank & N & Min & Max & Mean & Std.Dev \\
\hline \multirow{2}{*}{ ROA } & BUS & 32 & 0.08 & 11,20 & 1,8700 & 2,49468 \\
& UUS & 68 & 0,47 & 4,96 & 2,4106 & 1,01773
\end{tabular}

Sumber : Data yang diolah menggunakan spss 21

Berdasarkan hasil statistik deskriptif di atas, dapat diketahui bahwa jumlah sampel dalam penelitian ini adalah bank umum syariah dan unit usaha syariah pada periode tahun 2014-2017 yang terdiri dari 32 bank umum syariah dan 68 unit usaha syariah. Adapun ratarata nilai stabilitas keuangan bank yang diproksikan dengan rasio ROA pada bank umum syariah adalah sebesar 1,87 angka tersebut lebih kecil dari nilai rata-rata ROA pada unit usaha syariah sebesar 2,41 hal tersebut menunjukkan bahwa unit usaha syariah memiliki kemampuan yang lebih dalam menghasilkan laba dibandingkan dengan bank umum syariah. Adapun nilai minimum kualitas aset yang diproksikan oleh ROA pada bank umum syariah adalah sebesar 0,08 yaitu pada bank BRI syariah pada tahun 2014, sedangkan nilai minimum unit usaha syariah sebesar 0,47 yaitu pada bank CIMB Niaga pada tahun 2015. Nilai maksimum bank umum syariah adalah sebesar 11,20 yaitu pada bank Tabungan Pensiunan Nasional Syariah tahun 2017, sedangkan nilai maksimum unit usaha syariah adalah sebesar 4,96 yaitu pada BPD Sulawesi Barat dan Sulawesi Selatan di tahun 2016. Nilai penyimpangan bank umum syariah sebesar 2,49 sedangkan pada unit usaha syariah nilai penyimpangan sebesar 1,01 .

\section{Hasil Uji Hipotesis Independent Sample t Test}

Hasil uji hipotesis didapatkan dari hasil uji independent sample $t$ Test dengan menggunakan bantuan software SPSS versi 21. Hasil pengujian tersebut disajikan sebagai berikut ini:

\section{Efisiensi}

Uji hipotesis variabel efisiensi dilakukan dengan uji independet t Test, berikut hasil pengujian independent sampel t Test variabel efisiensi: 
Tabel 4

Hasil Uji Hipotesis Independent Sample t Test Levene's Test t-test for Equality of Means for Equality of Variances

F Sig. T Df Sig. (2- Mean Std. 95\% Confidence tailed) Differenc Error Interval of the $\mathrm{e}$ Differen Difference ce Lower Upper

Equal $\begin{array}{lllllllll}\text { variances } & \text { 142 } & \text { 707 } & 6,658 & 98 & \text { 000 } & 11,28300 & 1,69464,92005 & 14,64595\end{array}$

BOPO assumed

Equal

variances not

assumed

Sumber : Data yang diolah menggunakan spss 21

Berdasarkan tabel 4 di atas, maka dapat dianalisis bahwa hasil uji hipotesis independent $t$ Test memperoleh nilai t hitung untuk indikator efisiensi yang diproxykan oleh rasio BOPO sebesar $6.65 \%$ dengan rata-rata perbedaan sebesar $11,28 \%$ dimana rasio BOPO unit usaha syariah lebih rendah dibandingkan rasio bank umum syariah dan nilai signifikan sebesar $0 \%$ dimana nilai tersebut kurang dari $5 \%$ atau 0.05 . Hal ini menunjukkan bahwa terdapat perbedaan rata-rata rasio BOPO bank umum syariah dan unit usaha syariah. Diketahui dari nilai rata-rata bank umum syariah sebesar $89,55 \%$ dan unit usaha syariah sebesar 78,27\% maka dapat diartikan bahwa efisiensi yang diproxykan oleh rasio BOPO menunjukkan unit usaha syariah (UUS) lebih efisien dibandingkan dengan rasio BOPO bank umum syariah (BUS).

\section{Kualitas Aset}

Uji hipotesis variabel kualitas aset dilakukan dengan menggunakan uji independent $t$ Test, berikut hasil pengujian independent sampel $t$ Test variabel kualitas aset: 
Analis Perbandingan Bank Umum Syariah Dengan Unit Usaha Syariah Dari Aspek Efisiensi; Kualitas Asset Dan Stabilitas Keuangan (Periode Tahun 2014-2017)

Tabel 5

Hasil Uji Independent t Test Independent Samples Test

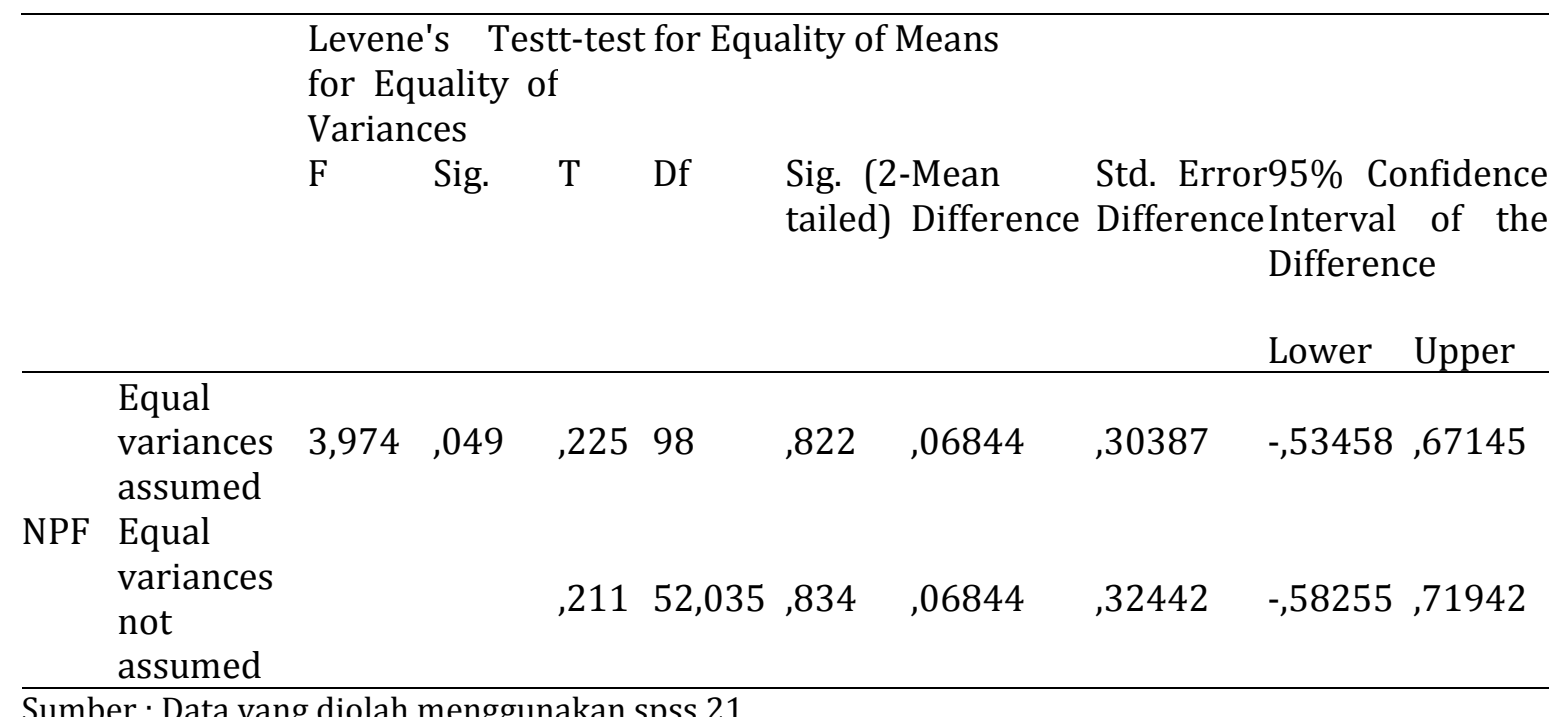

Sumber : Data yang diolah menggunakan spss 21

Berdasarkan tabel 5 di atas, maka dapat dianalisis bahwa hasil uji independent sampel t Test memperoleh nilai t hitung untuk indikator kualitas aset yang diproxykan oleh NPF sebesar 22,5\% dengan rata-rata perbedaan 0.06 dimana unit usaha syariah memiliki nilai rata-rata lebih rendah dibandingkan dengan bank umum syariah dan diperoleh nilai signifikan sebesar 0.822 artinya nilai tersebut lebih besar dari 0.05 hal ini menunjukkan bahwa tidak terdapat perbedaan antara bank umum syariah dengan unit usaha syariah. Meskipun tidak ada perbedaan yang signifikan antara NPF bank umum syariah dengan unit usaha syariah akan tetapi nilai rata-rata NPF bank umum syariah sebesar 1.96 dan nilai ratarata NPF unit usaha syariah sebesar 1.89 maka dapat diketahui bahwa NPF unit usaha syariah lebih rendah dibandingkan dengan NPF bank umum syariah.

\section{Stabilitas}

Uji hipotesis variabel kualitas aset dilakukan dengan menggunakan uji independent $\mathrm{t}$ Test, berikut hasil pengujian independent sampel t Test variabel kualitas aset: 
Tabel 6

Hasil Uji Independent Sampel t Test

Independent Samples Test

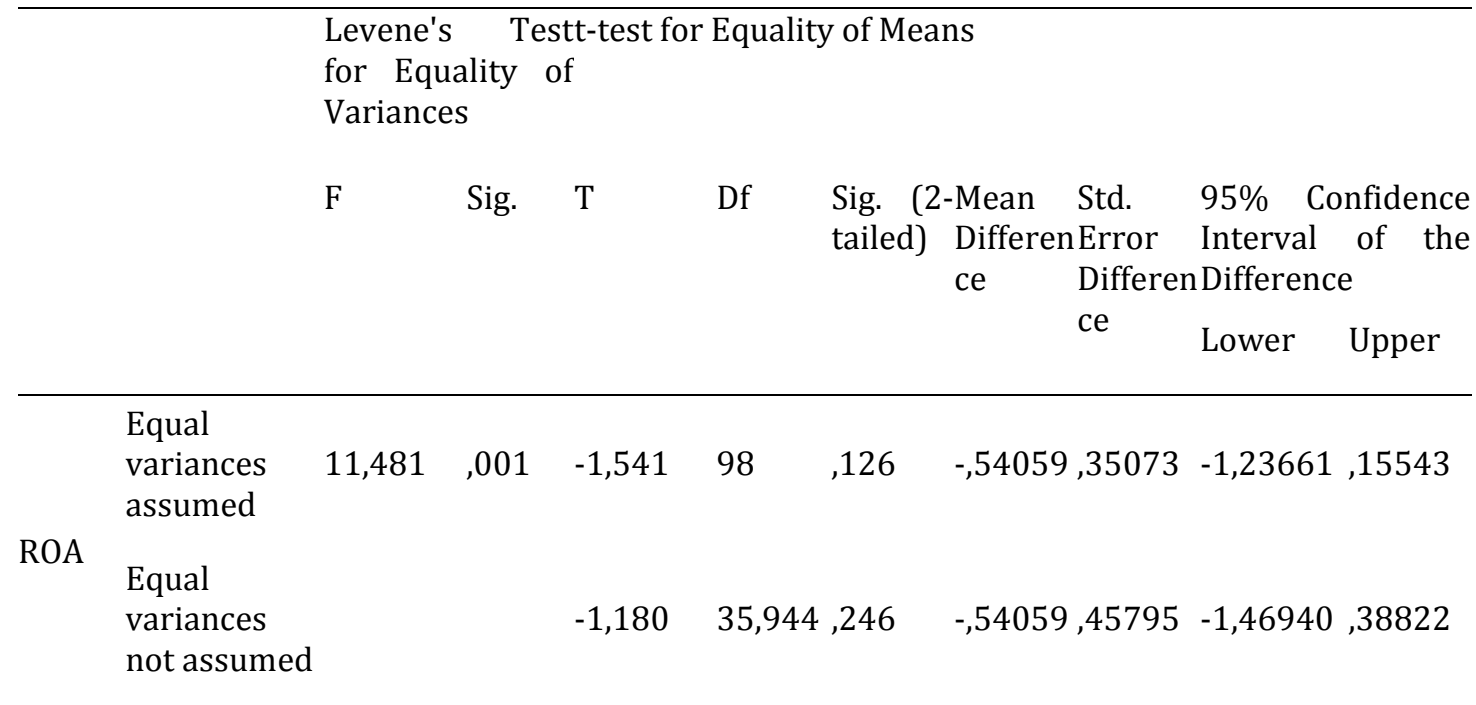

Sumber : Data yang diolah menggunakan spss 21

Berdasarkan tabel 6 di atas, maka dapat dianalisis bahwa hasil uji independent sampel $t$ Test memperoleh nilai thitung untuk indikator stabilitas yang diproksikan oleh ROA sebesar -1.54 dengan nilai rata-rata perbedaan sebesar -0.54 dimana ROA unit usaha syariah lebih tinggi dibandingkan dengan bank umum syariah dan diperoleh nilai signifikansi sebesar 1.26 artinya lebih besar dari 0.05 hal ini menunjukkan bahwa tidak terdapat perbedaan ratarata ROA antara bank umum syariah dengan unit usaha syariah. Meskipun tidak ada perbedaan yang signifikan antara ROA bank umum syariah dan ROA unit usaha syariah akan tetapi nilai rata-rata ROA unit usaha syariah sebesar 2.41 dan nilai rata-rata ROA bank umum syariah sebesar 1.87. Maka dapat diketahui bahwa ROA unit usaha syariah lebih baik dibandingkan dengan ROA bank umum syariah.

\section{Analisa Perbandingan Efisiensi BUS dengan UUS}

Efisiensi adalah optimalisasi dari sumber daya yang dimiliki yang bertujuan untuk mendapatkan hasil yang maksimal. Suatu perusahaan atau organisasi akan mengalokasikan dengan tepat sumber daya yang dikuasainya untuk dapat menghasilkan produk ataupun jasa yang memiliki kualitas dan daya saing sehingga produk dan jasa tersebut laku di masyarakat bahkan dapat menguasai pasar. ${ }^{14}$ Tujuan dari efisiensi tersebut adalah memberikan kontribusi pendapatan yang berkelanjutan sehingga efisiensi tidak dapat dikatakan sebagai aksi cost-cutting dari manajemen, melainkan mengalokasikan anggaran dengan tepat sasaran. Pengalokasian yang tepat sumber daya sesuai dengan prinsip syariah yaitu tidak melakukan pemborosan dan menghindari perilaku konsumtif. Sehingga menurut manajemen perusahaan dalam mengelola perusahaan dan organisasi yang berlandaskan prinsip syariah harus sederhana dan tidak berperilaku berlebih-lebihan. ${ }^{15}$ Selaras dengan efisiensi, dalam Q.S

14 Muazaroh, et.al., "Determinants of Bank Profit Efficiency: Evidence from Indonesia." International Journal of Economics and Finance Studies 4, no. 2 (2012): 164-73.

15 Suyoto Arief, "Konsumen Rasional Dalam Perspektif Islam." Islamic Economics Journal 1, no. 1 (2012): 17-30 Lihat juga, Hasan Baharun. "Manajemen Kinerja Dalam Meningkatkan Competitive Advantage Pada Lembaga 
Al-Baqarah ayat 168 juga menyatakan: " Hai sekalian manusia, makanlah yang halal lagi baik dari apa yang terdapat di bumi, dan janganlah kamu mengikuti langkah-langkah syaitan; karena sesungguhnya syaitan itu adalah musuh yang nyata bagimu." Selain itu juga terdapat pada Q.S Al-Isra ayat 27: "Sesungguhnya pemboros-pemboros itu adalah saudara-saudara syaitan dan syaitan itu adalah sangat ingkar kepada Tuhannya." Kemudian juga terdapat pada Q.S Al-A'raf ayat 31: "Hai anak Adam, pakailah pakaianmu yang indah di setiap (memasuki) mesjid, makan dan minumlah, dan janganlah berlebih-lebihan. Sesungguhnya Allah tidak menyukai orang-orang yang berlebih-lebihan." Beberapa rasio dapat digunakan untuk mengukur efisiensi yang salah satunya adalah rasio biaya operasional terhadap pendapatan operasional (BOPO) rasio ini digunakan untuk mengukur tingkat efisiensi dan kemampuan bank dalam mengelola kegiatan operasionalnya. ${ }^{16}$

Analisis perbedaaan efisiensi BUS dan UUS di Indonesia tahun 2014-2017 menunjukkan bahwa adanya perbedaan efisiensi BUS dan UUS di Indonesia tahun 20142017. Sesuai dengan hasil penelitian ini, maka dapat diketahui bahwa UUS lebih efisien jika dibandingkan dengan BUS. Selain itu berdasarkan penelitian terdahulu yang dilakukan oleh Wahab, Hosen dan Muhari, ${ }^{17}$ juga menemukan bahwa bank konvensional lebih efisien dibandingkan dengan bank syariah. Oleh karenanya, UUS yang nota bene operasionalnya masih menyatu dengan bank induknya (bank konvensional), maka terdapat peluang untuk melakukan join operasional dalam rangka penggunan biaya yang efektif. ${ }^{18}$ Hasil dari penelitian ini menjadi penting dikarenakan BUS tidak lebih efisien dibandingkan UUS yang nota bene operasionalnya disupervisi oleh bank konvensional sebagai bank induknya. Sehingga BUS dalam menjalankan operasionalnya harus mempertimbangkan aspek-aspek efisiensi dalam arti memiliki organisasi yang sederhana namun efektif dalam mengambil keputusan.

\section{Analisa Perbandingan Kualitas Pembiayaan antara BUS dengan UUS}

Definisi dari kualitas aset adalah semua total aktiva yang dimiliki oleh bank yang kemudian disalurkan, dan bertujuan untuk memperoleh penghasilan dalam rangka menjalankan fungsi intermediasi dan keberlanjutan operasional bank tersebut. ${ }^{19}$ Salah satu perhitungan pada rasio kualitas aktiva yang digunakan menurut SEBI/No.7/10/DPNP tanggal 13 Maret 2005 tentang Lembaga Pemeringkat dan Peringkat yang diakui oleh Bank Indonesia

Pendidikan Islam.” At-Tajdid: Jurnal Ilmu Tarbiyah 5, no. 2 (2016): 243-62; Lihat juga, Dewi Sukma Kristiani, "Kartu Kredit Syariah Dan Perilaku Konsumtif Masyarakat." Ahkam 14, no. 2 (2014): 287-96.

16 A.A. Yogi Prasanjaya and I Wayan Ramantha, "Analisis Pengaruh Rasio Car, Bopo, Ldr Dan Ukuran Perusahaan Terhadap Profitabilitas Bank Yang Terdaftar Di Bei,” E-Jurnal Akuntansi Universitas Udayana 4, no. 1 (2013): 23045; Nur Aini, "Pengaruh CAR, NIM, LDR, NPL, BOPO, Dan Kualitas Aktiva Produktif Terhadap Perubahan Laba (Studi Empiris Pada Perusahaan Perbankan Yang Terdaftar Di BEI) Tahun 2009-2011," Dinamika Akuntansi, Keuangan Dan Perbankan, 2, no. 1 (2013): 14-25; Nugroho and Bararah, "Pengaruh Good Corporate Governance Dan Biaya Operasional Dan Pendapatan Operasional (BOPO) Terhadap Stabilitas Keuangan Bank Umum Syariah Di Indonesia Tahun 2012-2017."

17 Wahab, Abdul, Muhammad Nadratuzzaman Hosen, and Syafaat Muhari. "Komparasi Efisiensi Teknis Bank Umum Konvensional (BUK) Dan Bank Umum Syariah (Bus) Di Indonesia Dengan Metode Data Envelopment Analysis (DEA)." Al-Iqtishad: Journal of Islamic Economics 6, no. 2 (2015): 179-94

18 Lucky Nugroho, Utami Wiwik, et al., "The Urgency of Allignment Islamic Bank to Increasing the Outreach," International Journal of Economics and Financial Issues 7, no. 4 (2017): 283-91, https://www.econjournals.com/index.php/ijefi/article/view/4493/pdf.

19 Zaenal Abidin and Endri, "Kinerja Efisiensi Teknis Bank Pembangunan Daerah : Pendekatan Data Envelopment Analysis ( DEA )," Jurnal Akuntansi Dan Keuangan 11 (2009): 21-29, http://jurnalakuntansi.petra.ac.id/index.php/aku/article/view/17863; Lucky Nugroho, Wayra Villaroel, and Wiwik Utami, "The Challenges of Bad Debt Monitoring Practices in Islamic Micro Banking," European Journal of Islamic Finance 11 (2017): 1-11. 
yang salah satu indikatornya adalah Non Performing Financing. Rasio ini mencakup kualitas aktiva kredit atau pebiayaan yang kriteria kolektibilitasnya meliputi (1) kurang lancar, (2) diragukan dan (3) macet, yang kemudian dibagi dengan total pembiayaan. Semakin besar nilai NPF, maka semakin besar kemungkinannya bank tersebut sedang menghadapi pembiayaan bermasalah. Tinggi atau rendahnya NPF dapat menunjukkan kemampuan manajemen bank dalam mengelola pembiayaan bermasalah yang disalurkan kepada nasabah oleh bank, semakin tinggi rasio NPF, maka akan semakin buruk kualitas pembiayaan bank sehingga dapat dikatakan manajemen dari bank tersebut tidak mampu melakukan mitigasi dengan baik. Lebih lanjut tingginya NPF juga akan berdampak menurunnya pendapatan dan laba bank yang juga akan berakibat terhadap berkurangnya modal dari bank tersebut, apabila pembiayaan bermasalah terus terjadi dan meningkat. ${ }^{20}$

Mitigasi risiko dalam Islam adalah suatu keharusan dan selaras dengan prinsip syariah yaitu al ghorm bil ghurmy dan al kharaj bid dhamany, dimana setiap terdapat keuntungan pasti terdapat potensi risiko dan risiko tersebut wajib untuk dimitigasi dan dikelola dengan baik. Dalam perbankan syariah mitigasi risiko pembiayaan telah menyatu dengan produk-produk yang ada melaui jenis-jenis akad dari bank syariah, baik itu akad jualbeli, kerjasama, sewa-menyewa maupun talangan. Setiap akad tersebut telah dilengkapi dengan rukun-rukunnya. Namun demikian dalam menjaga kualitas pembiayaan juga dipengaruhi oleh kemampuan dan profesionalisme dari account officer bank tersebut dalam menilai kelayakan calon nasabah. Kelayakan calon nasabah meliputi kemampuan membayar dan itikad baik dari nasabah tersebut untuk membayar. Lebih lanjut, dalam perspektif Islam terkait dengan kualitas pembiayaan tidak hanya menjadi tanggung jawab pihak bank saja tetapi juga menjadi tanggung jawab debitur untuk melunasi pinjaman tersebut. Oleh karenanya dengan prinsip-prinsip tersebut, maka risiko terjadinya asymetri information dan moral hazard dalam penyaluran pembiayaan dapat di mitigasi sejak awal.21 Implementasi mitigasi risiko berdasarkan prinsip-prinsip syariah menjadi tanggung jawab bersama, baik dari pihak internal bank dan masyarakat (nasabah) yang menurut Suganda, ${ }^{22}$ pondasi dari mitigasi risiko sesuai perspektif Islam adalah sebagai berikut:

Pertama, Tauhid: Seluruh pihak memahami dan melaksanakan sumber-sumber hukum Islam (Al-Qur'an, hadis dan Ijtihad); Kedua Adil: Tidak terdapat aspek-aspek yang saling merugikan diantara para pihak terkait; Ketiga Nubuwah: Seluruh pihak menjunjung tinggi nilai-nilai siddiq (jujur), amanah (dapat dipercaya), tabligh (menyampaikan yang benar), fathonah (cerdas/tepat); Keempat Khilafah: Memiliki visi dan misi yang sama, yaitu melaksanakan perintah Allah SWT dan menjauhi larangan-Nya dalam rangka mewujudkan kesejahteraan ummat (maslahat); dan Kelima $M a^{\prime} a d$ : Seluruh pihak memiliki persepsi dan tujuan yang sama, yaitu mencapai Falah, bahwa kehidupan didunia bukan akhir dari segalagalanya, akan tetapi akhirat yang menjadi tujuan akhirnya. ${ }^{23}$

Aspek kualitas penyaluran pembiayaan pada bank umum syariah berdasarkan hasil penelitian tidak terdapat perbedaan yang signifikan namun apabila ditinjau lebih lanjut kualitas aset dari unit usaha syariah lebih baik terhadap kualitas aset bank umum syariah.

\footnotetext{
20 Dewi Ayu Anjani and Ni Ketut Purnawati, "Pengaruh Non Performing Loan (Npl), Likuiditas Dan Rentabilitas Terhadap Rasio Kecukupan Modal," Bisnis Dan Manajemen (Jbima) 2, no. 1 (2014): 1-19; Nugroho and Anisa, "Pengaruh Manajemen Bank Induk, Kualitas Aset, Dan Efisiensi Terhadap Stabilitas Bank Syariah Di Indonesia (Periode Tahun 2013-2017)."

21 Helmut Bester, "The Role of Collateral in Credit Markets with Imperfect Information," European Economic Review 31 (1987): 887-99.

22 Asep Dadan Suganda, "Mengurangi Tingkat Risiko Dengan Manajemen Islami." Jurnal Ekonomi Islam 6, no. 2 (2015): 1-14.

${ }^{23}$ Fadllan, "REKONSTRUKSI PEMBANGUNAN EKONOMI BERBASIS ISLAM Telaah Pemikiran M. Umer Chapra," NUANSA: Jurnal Penelitian Ilmu Sosial dan Keagamaan Islam 15, no. 2 (2018): 393-426.
} 


\section{Analis Perbandingan Bank Umum Syariah Dengan Unit Usaha Syariah Dari Aspek Efisiensi; Kualitas Asset Dan Stabilitas Keuangan (Periode Tahun 2014-2017)}

Hasil penelitian yang sama yang telah dilakukan oleh Satibi dkk., ${ }^{24}$ juga menyatakan bahwa bank umum syariah memilliki kualitas aset yang tidak lebih baik dibandingkan dengan bank konvensional. Terdapat beberapa kemungkinan terkait dengan belum baiknya kualitas aset atau pembiayaan dari BUS yang antara lain adalah: (i) Sumber daya manusia dari BUS belum memiliki kapasitas dan kompetensi yang lebih baik dibandingkan dengan UUS yang nota bene masih disupport oleh bank induknya (bank konvensional); (ii) Pertumbuhan BUS dalam menyalurkan pembiayaan belum dimitigasi secara baik dengan prinsip kehati-hatian.

\section{Analisa perbandingan Stabiltas antara BUS dengan UUS}

Menurut Sarwono, dan Warjiyo, ${ }^{25}$ stabilitas sistem perbankan dan sistem moneter merupakan dua aspek yang saling terkait dan menentukan satu sama lain, stabilnya sistem perbankan secara umum dicerminkan dengan kondisi industri perbankan yang sehat dan berjalannya fungsi intermediasi perbankan dalam memobilisasi simpanan masyarakat untuk disalurkan dalam bentuk pembiayaan kepada dunia usaha. Apabila kondisi ini terpelihara, maka proses perputaran uang dan mekanisme transmisi kebijakan moneter dalam perekonomian yang sebagian berlangsung melalui sistem perbankan juga dapat berjalan dengan baik. Stabilnya sistem perbankan akan menentukan efektivitas pelaksanaan kebijakan moneter. ${ }^{26}$ Pada saat krisis keuangan tahun 1998 biaya yang dibutuhkan untuk menyelamatkan stabilitas keuangan sangatlah tinggi, selain itu juga diperlukan waktu yang lama untuk menumbuhkan kepercayaan masyarakat terhadap sistem keuangan. ${ }^{27}$ Sistem keuangan yang tidak stabil cenderung akan rentan terhadap gejolak sehingga mengganggu perputaran roda perekonomian, kondisi tersebut disampaikan oleh Beck, et.al., ${ }^{28}$ dalam penelitian Islamic vs conventional bank (bussines model, efisiensi and stability) dengan stabilitas perbankan yangt diproksikan dengan Z score, ROA dan CAR.

Dari aspek stabilitas yang diproksikan dengan ROA, pada penelitian menunjukkan bahwa stabilitas dari bank umum syariah juga tidak lebih baik apabila dibandingkan dengan unit usaha syariah. Kondisi stabilitas bank syariah perlu ditingkatkan juga sejalan dengan penelitian sebelumnya yang dilakukan oleh Bekc, et.al., ${ }^{29}$ dimana stabilitas bank umum syariah masih di bawah stabilitas dari bank umum konvensional.

Hasil dari pembahasan pada penelitian ini, menunjukkan bahwa dalam mengelola bank syariah masih terdapat tantangan. Tantangan tersebut antara lain:

- Eksistensi perbankan syariah pada indutri perbankan di Indonesia relatif masih baru. Gap keberadaan bank syariah dengan bank konvensional di Indonesia sangat jauh, yaitu lebih

\footnotetext{
${ }^{24}$ Satibi, et.al., "A Comparison of Sharia Banks and Conventional Banks in Terms of Efficiency, Asset Quality and Stability in Indonesia for the Period 2008-2016." International Journal of Commerce and Finance 4, no. 1 (2018): 134-49.

${ }^{25}$ Hartadi A. Sarwono, dan Perry Warjiyo. "Mencari Paradigma Baru Manajemen Moneter Dalam SIstem Nilai Tukar Fleksibel: Suaru Pemikiran Untuk Penerapannya Di Indonesia." Buletin Ekonomi Moneter Dan Perbankan 1, no. 1 (2003): 5-23. https://doi.org/10.21098/bemp.v1i1.158.

26 (Arianti et al., 2016; Sarwono \& Warjiyo, 2003; Wibisono, 2009)

27 Elly Karmeli and Siti Fatimah, "Krisis Ekonomi Indonesia," Journal of Indonesian Applied Economics 2, no. 2 (2008): 164-73, https://doi.org/10.1002/cae.20304; Hikmahanto Juwana, "Analisa Ekonomi Atas Hukum Perbankan," Jurnal Hukum \& Pembangunan 28, no. 1-3 (2017): 83, https://doi.org/10.21143/jhp.vol28.no13.537; M Arief Amrullah, "Politik Hukum Pidana Dalam Korban Kejahatan Ekonomi Di Bidang Perbankan," Jurnal Hukum 9, no. 21 (2002): 23-43.

28 (Beck et al., 2010)

${ }^{29}$ Beck, Kunt, and Merrouche, "Islamic Vs . Conventional Banking : Business Model , Efficiency and Stability Islamic vs . Conventional Banking Business Model , Efficiency and Stability"; Satibi, Nugroho, and Utami, "A Comparison of Sharia Banks and Conventional Banks in Terms of Efficiency, Asset Quality and Stability in Indonesia for the Period 2008-2016."
} 
dari satu abad (antara bank rakyat Indonesia-1896 dengan bank muamalat-1992). Oleh karenanya diperlukan intervensi pemerintah berupa kebijakan untuk dapat memajukan bank syariah di Indonesia, karena apabila mengandalkan pertumbuhan organik, maka bank syariah membutuhkan dana investasi yang besar untuk dapat bersaing dengan bank konvensional; 30

- Ketertinggalan bank syariah baik dalam keunggulan teknologi informasi, sumber daya insani dan juga jumlah outlet menjadikan bank syariah belum dapat bersaing untuk mendapatkan nasabah yang berkualitas, dan juga belum mampu untuk menjalankan operasionalnya secara independen. Oleh karenanya bank syariah sangat ketergantungan dengan bank induk (bank pemegang saham) baik itu bank umum syariah, maupun unit usaha syariah; ${ }^{31}$

- Permodalan bank syariah yang masih perlu ditingkatkan dalam melakukan ekspansi bisnisnya. ${ }^{32}$ Saat ini bank umum syariah masih sangat tergantung dengan pemegang saham yang notabene adalah bank konvensional sehingga diperlukan terobosan agar market share industri perbankan syariah meningkat dan memiliki kemandirian dalam hal sumber dana;

- Seharusnya pembukaan jaringan bank syariah tidak hanya mengutamakan profit atau keuntungan semata, akan tetapi juga harus mempertimbangkan lokasi-lokasi di pedesaan yang bertujuan untuk meningkatkan literasi keuangan syariah.

\section{PENUTUP}

Pengelolaan bank umum syariah memerlukan terobosan dan solusi yang tepat dalam rangka meningkatkan kinerjanya. Solusi dan terobosan tersebut merupakan tanggung jawab bersama dari seluruh stakeholder bank industri perbankan syariah baik dari pemerintah, masyarakat, akademisi, pihak internal bank syariah dan sebagainya. Seiring dengan telah tedapatnya Komite Nasional Keuangan Syariah (KNKS) dan juga komitmen dari pemerintah untuk menjadikan Indonesia sebaga Islamic Financial and Islamic Business Center, maka sudah selayaknya pemerintah dapat mengakuisisi seluruh Bank Umum Syariah yang dimiliki oleh Bank BUMN saat ini untuk dijadikan Bank Syariah milik negara (Bank BUMN Syariah). Dengan kebijakan dan solusi tersebut, maka diharapkan ketergantungan bank syariah terhadap bank konvensional dapat diminimalkan. Selain itu dengan kuatnya modal bank umum syariah, maka bank umum syariah akan mampu menyediakan informasi teknologi yang up to date, profesionalime karyawan melalui pemberian training dan pendidikan yang layak serta terdapatnya jaringan-jaringan yang tidak hanya dipusat kota akan tetapi ke desadesa yang sulit terjangkau. Kajian pembukaan jaringan bank syariah seharusnya tidak hanya didasarkan atas aspek profit semata, akan tetapi juga mempertimbangkan ketersediaan bank syariah pada lokasi tersebut dan kebutuhan masyarakat desa akan layanan syariah.

\section{DAFTAR PUSTAKA}

Abidin, Zaenal, and Endri. "Kinerja Efisiensi Teknis Bank Pembangunan Daerah : Pendekatan Data Envelopment Analysis ( DEA )." Jurnal Akuntansi Dan Keuangan 11 (2009): 2129. http://jurnalakuntansi.petra.ac.id/index.php/aku/article/view/17863.

\footnotetext{
${ }^{30}$ Nugroho et al., "Maslahah and Strategy to Establish A Single State-Owned Islamic Bank in Indonesia"; Lucky Nugroho, Wiwik Utami, et al., "The Urgency of Allignment Islamic Bank to Increasing the Outreach," International Journal of Economics and Financial Issues 7, no. 4 (2017): 283-91, https://www.econjournals.com/index.php/ijefi/article/view/4493/pdf.

31 (Nugroho \& Anisa, 2018; Nugroho, Villaroel, Utami, 2017; Sukmadilaga \& Nugroho, 2017)

32 Lucky Nugroho et al., "Islamic Banking Capital Challenges to Increase Business Expansion (Indonesia Cases)," International Journal of Commerce and Finance 3, no. 2 (2017): 1-10.
} 
Agustiningrum, Riski. "Analisis Pengaruh CAR, NPL, Dan LDR Terhadap Profitabilitas Pada Perusahaan Perbankan." Jurnal Manajemen Universitas Udayana 2, no. 8 (2013): 885902.

Ahmad, Suraya, and Abdul Rahim Abdul Rahman. "The Efficiency of Islamic and Conventional Commercial Banks in Malaysia." International Journal of Islamic and Middle Eastern Finance and Management 5, no. 3 (2012): 241-63. https://doi.org/10.1108/17538391211255223.

Aini, Nur. "Pengaruh CAR, NIM, LDR, NPL, BOPO, Dan Kualitas Aktiva Produktif Terhadap Perubahan Laba (Studi Empiris Pada Perusahaan Perbankan Yang Terdaftar Di BEI) Tahun 2009-2011." Dinamika Akuntansi, Keuangan Dan Perbankan, 2, no. 1 (2013): 14-25.

Amrullah, M Arief. "Politik Hukum Pidana Dalam Korban Kejahatan Ekonomi Di Bidang Perbankan." Jurnal Hukum 9, no. 21 (2002): 23-43.

Anisah, Lubis. "Pengaruh Tingkat Kesehatan Bank Terhadap Pertumbuhan Laba Pada BPR Di Indonesia." Jurnal Ekonomi Dan Keuangan, 1, no. 4 (2013): 27-37.

Anjani, Dewi Ayu, and Ni Ketut Purnawati. "Pengaruh Non Performing Loan (Npl), Likuiditas Dan Rentabilitas Terhadap Rasio Kecukupan Modal." Bisnis Dan Manajemen (Jbima) 2, no. 1 (2014): 1-19.

Arafah, Willy, and Lucky Nugroho. "Maqhashid Sharia in Clean Water Financing Business Model at Islamic Bank." International Journal of Business and Management Invention (IJBMI) 5, no. 2 (May 1, 2016): 22-32. http://www.ijbmi.org/papers/Vol(5)2/Version -3/D05203022032.pdf.

Arianti, Dwinur, Rita Andini, and Rina Arifati. "Pengaruh BOPO,NIM, NPL, Dan CAR Terhadap Jumlah Penyaluran Kredit Pada Perusahaan Perbankan Yang Go Publik Di Bursa Efek Indonesia Periode Tahun 2010-2014." Journal of Accounting 2, no. 2 (2016).

Arief, Suyoto. "Konsumen Rasional Dalam Perspektif Islam." Islamic Economics Journal 1, no. 1 (2012): 17-30.

Asiedu, Elizabeth. "The Role of Natural Resources, Market Size, Government Policy, Institutions and Political Instability." World Institute for Development Economics Research Working Paper 2005, no. 24 (2005).

Bachruddin. "Pengukuran Tingkat Efisiensi Bank Syariah Dan Bank Konvensional Di Indonesia Dengan Formula David Cole's Roe for Bank." Jurnal Siasat Bisnis (JSB) 11, no. 1 (2006): 67-80.

Baharun, Hasan. "Manajemen Kinerja Dalam Meningkatkan Competitive Advantage Pada Lembaga Pendidikan Islam." At-Tajdid: Jurnal Ilmu Tarbiyah 5, no. 2 (2016): 243-62.

Beck, Thorsten, Asli Demirguc Kunt, and Ourda Merrouche. "Islamic Vs . Conventional Banking : Business Model , Efficiency and Stability Islamic vs . Conventional Banking Business Model , Efficiency and Stability." Journal of Banking \& Finance 37, no. October (2010): 433-47. https://doi.org/10.1016/j.jbankfin.2012.09.016.

Bester, Helmut. "The Role of Collateral in Credit Markets with Imperfect Information." European Economic Review 31 (1987): 887-99.

Cowton, C J. "Integrity , Responsibility and Affinity: Three Aspects of Ethics in Banking 1." Business Ethics: A European Review 11, no. 4 (2002): 393-400.

Dienillah, Azifah Azka, and Lukytawati Anggraeni. "Dampak Inklusi Keuangan Terhadap Stabilitas Sistem Keuangan Di Asia." Buletin Ekonomi Moneter Dan Perbankan 18, no. 4 (2016): 409-30.

Entrisnasari, Fantika Vera. "Analisis Portofolio Optimum Saham Syariah Menggunakan Mean Semivarian." JURNAL FOURIER 4, no. 1 (2015): 41-57. 
Fadllan, "REKONSTRUKSI PEMBANGUNAN EKONOMI BERBASIS ISLAM Telaah Pemikiran M. Umer Chapra." NUANSA: Jurnal Penelitian Ilmu Sosial dan Keagamaan Islam 15, no. 2 (2018): 393-426.

Friedman, Milton. "The Role of Monetary Policy." Essential Readings in Economics LVIII, no. 1 (1968): 215-31.

Haneef, Shahbaz, Mansoor Ali Rana, and Yasir Karim. "Impact of Risk Management on NonPerforming Loans and Profitability of Banking Sector of Pakistan Hailey College of Commerce University of the Punjab Hafiz Muhammad Ishaq Federal Urdu University of Arts , Science and Technology." International Journal of Business and Social Science 3, no. 7 (2012): 307-15.

Haryati, Sri. "Pertumbuhan Kredit Perbankan Di Indonesia: Intermediasi Dan Pengaruh Variabel Makro Ekonomi." Jurnal Keuangan Dan Perbankan 13, no. 2 (2009): 299-310.

Hayo, Bernd. "Inflation Culture, Central Bank Independence and Price Stability." European Journal of Political Economy 14, no. January (1998): 241-63.

Huri, Mumu Daman, and Indah Susilowati. "Pengukuran Efisiensi Relatif Emiten Perbankan Dengan Metode Data Envelopment Analysis (DEA) (Studi Kasus: Bank-Bank Yang Terdaftar Di Bursa Efek Jakarta Tahun 2002)." Jurnal Dinamika Pembangunan (JDP) 1, no. 2 (2004): 95-110.

Jensen, M, and W Meckling. "Theory of the Firm: Managerial Behaviour, Agency Costs and Ownership." Strategic Management Journal 21, no. 4 (1976): 1215-24. http://search.ebscohost.com/login.aspx?direct=true\&db=buh\&AN=12243301\&site=e host-live.

Juwana, Hikmahanto. "Analisa Ekonomi Atas Hukum Perbankan." Jurnal Hukum \& Pembangunan 28, no. 1-3 (2017): 83. https://doi.org/10.21143/jhp.vol28.no1-3.537.

Karmeli, Elly, and Siti Fatimah. "Krisis Ekonomi Indonesia." Journal of Indonesian Applied Economics 2, no. 2 (2008): 164-73. https://doi.org/10.1002/cae.20304.

Kim, Jongwook, and Joseph T Mahoney. "Property Rights Theory , Transaction Costs Theory, and Agency Theory: An Organizational Economics Approach to Strategic Management." Managerial and Decision Economics 26, no. January (2002): 223-42. https://doi.org/10.1002/mde.1218.

Kristianti, Dewi Sukma. "Kartu Kredit Syariah Dan Perilaku Konsumtif Masyarakat." Ahkam 14, no. 2 (2014): 287-96.

Muazaroh, Tandelilin Eduardus, Suad Husnan, and Mamduh M Hanafi. "Determinants of Bank Profit Efficiency: Evidence from Indonesia." International Journal of Economics and Finance Studies 4, no. 2 (2012): 164-73.

Nugroho, Lucky, and Nurul Anisa. "Pengaruh Manajemen Bank Induk, Kualitas Aset, Dan Efisiensi Terhadap Stabilitas Bank Syariah Di Indonesia (Periode Tahun 2013-2017)." Inovbiz: Jurnal Inovasi Bisnis 6, no. 2 (2018): 114-22.

Nugroho, Lucky, Ahmad Badawi, and Nurul Hidayah. "Discourses of Sustainable Finance Implementation in Islamic Bank (Cases Studies in Bank Mandiri Syariah 2018)." International Journal of Financial Research 10, no. 6 (2019): 108-17. https://doi.org/10.5430/ijfr.v10n6p108.

Nugroho, Lucky, and Herda Nezzim Bararah. "Pengaruh Good Corporate Governance Dan Biaya Operasional Dan Pendapatan Operasional (BOPO) Terhadap Stabilitas Keuangan Bank Umum Syariah Di Indonesia Tahun 2012-2017." Inovbiz: Jurnal Inovasi Bisnis 6, no. 2 (2018): 160-69.

Nugroho, Lucky, Nurul Hidayah, and Ahmad Badawi. "The Islamic Banking, Asset Quality: 'Does Financing Segmentation Matters' (Indonesia Evidence)." Mediterranean Journal of Social Sciences 9, no. 5 (2018): 221-35. https://doi.org/10.2478/mjss-2018-0154. 


\section{Analis Perbandingan Bank Umum Syariah Dengan Unit Usaha Syariah Dari Aspek Efisiensi; Kualitas Asset Dan Stabilitas Keuangan (Periode Tahun 2014-2017)}

Nugroho, Lucky, Tengku Chandra Husnadi, Wiwik Utami, and Nurul Hidayah. "Maslahah and Strategy to Establish A Single State-Owned Islamic Bank in Indonesia." Tazkia Islamic Finance and Business Review 10, no. 1 (June 1, 2017): 17-33. http://www.tifbrtazkia.org/index.php/TIFBR/article/view/97/106.

Nugroho, Lucky, Wiwik Utami, Caturida Meiwanto Doktoralina, Soeharjoto Soekapdjo, and Tengku Chandra Husnadi. "Islamic Banking Capital Challenges to Increase Business Expansion (Indonesia Cases)." International Journal of Commerce and Finance 3, no. 2 (2017): 1-10.

Nugroho, Lucky, Wiwik Utami, Citra Sukmadilaga, and Tettet Fitrijanti. "The Urgency of Allignment Islamic Bank to Increasing the Outreach." International Journal of Economics and Financial Issues 7, no. 4 (2017): 283-91. https://www.econjournals.com/index.php/ijefi/article/view/4493/pdf.

Nugroho, Lucky, Wayra Villaroel, and Wiwik Utami. "The Challenges of Bad Debt Monitoring Practices in Islamic Micro Banking." European Journal of Islamic Finance 11 (2017): 111.

Nugroho, Lucky, Utami Wiwik, Sukmadilaga Citra, and Fitrijanti Tettet. "The Urgency of Allignment Islamic Bank to Increasing the Outreach." International Journal of Economics and Financial Issues 7, no. 4 (2017): 283-91. https://www.econjournals.com/index.php/ijefi/article/view/4493/pdf.

Prasanjaya, A.A. Yogi, and I Wayan Ramantha. "Analisis Pengaruh Rasio Car, Bopo, Ldr Dan Ukuran Perusahaan Terhadap Profitabilitas Bank Yang Terdaftar Di Bei." E-Jurnal Akuntansi Universitas Udayana 4, no. 1 (2013): 230-45.

Premachandra, I M, and Jing Shi. "Measuring the Relative Efficiency of Fund Management Strategies in New Zealand Using a Spreadsheet-Based Stochastic Data Envelopment Analysis Model." Omega 26, no. 2 (1998): 319-31. https://doi.org/10.1016/S03050483(98)00002-4.

Raharjo, Eko. "Teori Agensi Dan Teori Stewarship Dalam Perspektif Akuntansi." Fokus Ekonomi 2, no. 1 (2007): 37-46.

Sarwono, Hartadi A., and Perry Warjiyo. "Mencari Paradigma Baru Manajemen Moneter Dalam SIstem Nilai Tukar Fleksibel: Suaru Pemikiran Untuk Penerapannya Di Indonesia." Buletin Ekonomi Moneter Dan Perbankan 1, no. 1 (2003): 5-23. https://doi.org/10.21098/bemp.v1i1.158.

Satibi, Elsa, Lucky Nugroho, and Wiwik Utami. "A Comparison of Sharia Banks and Conventional Banks in Terms of Efficiency, Asset Quality and Stability in Indonesia for the Period 2008-2016." International Journal of Commerce and Finance 4, no. 1 (2018): 134-49.

Satibi, Elsa, and Wiwik Utami. "Studi Komparasi Efisiensi, Kualitas Aset Dan Stabilitas Pada Bank Umum Syariah Dan Bank Umum Konvensional Di Indonesia Periode 20102014." Jurnal Ilmu Ekonomi Dan Sosial 4, no. 1 (2015): 104-14.

Soekapdjo, Soeharjoto, Debbie Aryani Tribudhi, and Lucky Nugroho. "Pengaruh Fundamental Ekonomi Dan Kinerja Keuangan Terhadap Kredit Bermasalah Pada Bank Syariah Di Indonesia." Ekonika: Jurnal Ekonomi Universitas Kadiri 4, no. 2 (2019): 126. https://doi.org/10.30737/ekonika.v4i2.327.

Sudarsono, Heri. "Dampak Krisis Keuangan Global Terhadap Perbankan Di Indonesia: Perbandingan Antara Bank Konvensional Dan Bank Syariah." La_Riba 3, no. 1 (2009): 12-23. https://doi.org/10.20885/lariba.vol3.iss1.art2.

Suganda, Asep Dadan. "Mengurangi Tingkat Risiko Dengan Manajemen Islami." Jurnal Ekonomi Islam 6, no. 2 (2015): 1-14. 
Sukmadilaga, Citra, and Lucky Nugroho. Pengantar Akuntansi Perbankan Syariah "Prinsip, Praktik Dan Kinerja." Pusaka Media, Bandar Lampung, Indonesia, 2017.

Utami, Wiwik, and Lucky Nugroho. "Potential Big Bath Accounting Practice in CEO Changes (Study on Manufacturing Companies Listed in Indonesia Stock Exchange)." International Journal of Accounting and Finance Studies 1, no. 2 (2018): 202-15. https://doi.org/10.22158/ijafs.v1n2p202.

Vania, Adela Sarah, Erik Nugraha, and Lucky Nugroho. "Does Earning Management Happen in Islamic Bank? (Indonesia and Malaysia Comparison)." International Journal of Commerce and Finance 4, no. 2 (2018): 47-59.

Wahab, Abdul, Muhammad Nadratuzzaman Hosen, and Syafaat Muhari. "Komparasi Efisiensi Teknis Bank Umum Konvensional (BUK) Dan Bank Umum Syariah (Bus) Di Indonesia Dengan Metode Data Envelopment Analysis (DEA)." Al-Iqtishad: Journal of Islamic Economics 6, no. 2 (2015): 179-94. https://doi.org/10.15408/ijies.v6i2.1229.

Wibisono, Yusuf. "Politik Ekonomi UU Perbankan Syariah Peluang Dan Tantangan Regulasi Industri Perbankan Syariah." Jurnal Ilmu Administrasi Dan Organisasi 16 (2009): 10515. 